\title{
ANALISIS KOMODITAS UNGGULAN TANAMAN PANGAN DAN HORTIKULTURA DI KABUPATEN MEMPAWAH
}

\author{
ADE IRMAYADI ${ }^{1)}$, ERLINDA YURISINTHAE $^{2)}$, ADI SUYATNO $^{2)}$ \\ 1) Alumni Magister Manajemen Agribisnis Fakultas Pertanian \\ Universitas Tanjungpura Pontianak \\ 2) Staf Pengajar Fakultas Pertanian Universitas Tanjungpura Pontianak \\ email:anak.kunyit@gmail.com
}

\begin{abstract}
Mempawah Regency Government has a mission to improving the economy that oriented to the community. The goal is to develop the economy through food security (agriculture commodity crops, horticulture, livestock, fisheries and biodiversity) and reinforced by forests management and plantations to improve the welfare of farmers. Mempawah regency is one of the regencys that the economic life of the people still depend on agribusiness system, particularly the agricultural sector. Based on the (Gross Regional Domestic Product) GRDP value of Mempawah Regencys years 2008 to 2012 the agricultural sector, especially the food crops subsector has the highest contribution to Mempawah Regency's GRDP compared to other subsectors. The goal of this study is to analyze which subsector that became the basis of agricultural sector in the Mempawah Regency and the leading commodity of food crops and horticulture. This study uses three analysis tools i.e Dynamic Location Quotient Analysis to analyze what is the basis of the agricultural sector in the Mempawah Regency. Shift-Share Analysis and Growth Ratio Model Analysis to analyze any commodity which is the leading commodities of food crops and horticulture. The results from this study is, subsectors which are the basis of the agricultural sector in the Mempawah Regency is the food crops, forestry, and fishery subsector. The leading commodity in the Mempawah Regency of food crops are rice, the leading commodities of vegetables are cucumbers and kangkung, and the leading commodity of fruits are bananas.
\end{abstract}

Keywords : Basis, Leading Sector, Food Crops Subsector and Horticulture

\section{PENDAHULUAN}

\section{Latar Belakang}

Indonesia dikenal sebagai negara agraris yang berarti negara yang mengandalkan sektor pertanian baik sebagai sumber matapencarian masyarakat maupun sebagai sumber penopang pembangunan (Saragih, 2001). Berkaitan dengan hal tersebut, untuk menjadikan sektor pertanian sebagai sektor unggulan dalam pembangunan ekonomi nasional, transformasi pembangunan pertanian harus dilakukan kearah pembangunan agribisnis. Pembangunan agribisnis memiliki keterkaitan yang erat dengan pembangunan daerah (Didu, 2000).

Kabupaten Mempawah merupakan salah satu kabupaten yang kehidupan perekonomian masyarakatnya masih bergantung kepada sistem agribisnis, dalam hal ini khususnya sektor pertanian. Terlihat pada nilai Produk Domestik Regional Bruto (PDRB) Kabupaten Mempawah dimana sektor pertanian merupakan 
penyumbang PDRB terbesar dibandingkan sektor perekonomian lainnya. Pertumbuhan ekonomi Kabupaten Mempawah periode 2008 - 2012 berfluktuasi.

Tabel 1. Produk Domestik Regional Bruto Atas Dasar Harga Konstan 2000 Kabupaten Pontianak Tahun 2008 - 2012 (Jutaan Rupiah)

\begin{tabular}{|c|c|c|c|c|c|c|}
\hline No & Sektor & 2008 & 2009 & 2010 & $2011^{r)}$ & $\left.2012^{*}\right)$ \\
\hline \multirow[t]{6}{*}{1} & Pertanian & $308.269,98$ & $311.863,56$ & $310.666,95$ & $334.882,59$ & $334.138,26$ \\
\hline & - Tanaman Bahan Makanan & $129.655,29$ & $130.607,89$ & $121.472,82$ & $136.664,52$ & $128.260,76$ \\
\hline & - Tanaman Perkebunan & $42.471,48$ & $43.759,71$ & $47.775,11$ & $51.315,11$ & $54.098,09$ \\
\hline & - Peternakan dan hasilnya & $67.233,45$ & $73.029,20$ & $79.749,71$ & $84.080,06$ & $87.188,29$ \\
\hline & - Kehutanan & $17.497,21$ & $16.273,47$ & $15.532,59$ & $14.732,51$ & $14.033,97$ \\
\hline & - Perikanan & $51.412,55$ & $48.193,29$ & $46.136,73$ & $48.090,40$ & $50.557,16$ \\
\hline 2 & Pertambangan dan Penggalian & $2.569,47$ & $3.571,37$ & $3.773,81$ & $4.009,63$ & $4.465,90$ \\
\hline 3 & Industri Pengolahan & $180.478,42$ & $184.670,34$ & $188.711,34$ & $193.470,60$ & $199.395,41$ \\
\hline 4 & Listrik, Gas dan Air Bersih & $15.060,85$ & $16.052,99$ & $17.321,92$ & $18.450,70$ & $19.324,23$ \\
\hline 5 & Bangunan & $49.945,54$ & $52.251,76$ & $54.832,57$ & $57.897,95$ & $62.383,81$ \\
\hline 6 & $\begin{array}{l}\text { Perdagangan, Hotel dan } \\
\text { Restoran }\end{array}$ & $221.156,43$ & $229.306,30$ & $237.168,51$ & $250.132,07$ & $260.271,95$ \\
\hline 7 & $\begin{array}{l}\text { Pengangkutan dan } \\
\text { Komunikasi }\end{array}$ & $45.992,90$ & $47.425,12$ & $48.687,41$ & $50.119,36$ & $51.845,91$ \\
\hline 8 & $\begin{array}{l}\text { Keu, Persewaan dan Jasa } \\
\text { Perush }\end{array}$ & $49.257,48$ & $51.053,26$ & $53.147,19$ & $55.441,88$ & $58.291,25$ \\
\hline \multirow[t]{2}{*}{9} & Jasa-jasa & $307.074,78$ & $299.221,65$ & $306.515,89$ & $315.595,25$ & $330.515,14$ \\
\hline & PDRB & $1.179 .805,85$ & $1.195 .416,33$ & $1.220 .825,99$ & $1.280 .000,04$ & $1.320 .631,87$ \\
\hline
\end{tabular}

Sumber : BPS Kabupaten Pontianak, 2013

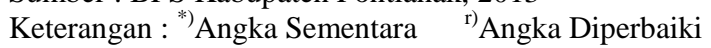

Kabupaten Mempawah mempunyai jumlah penduduk sebesar 241.248 jiwa pada tahun 2012 dengan luas wilayah 1.276,90 $\mathrm{km}^{2}$ dan terdiri dari 9 Kecamatan, 7 Kelurahan dan 60 Desa. Struktur perekonomian Kabupaten Mempawah masih didominasi oleh sektor pertanian yaitu sebesar 27,24 persen. Pola struktur ini masih tetap sama dibanding tahun sebelumnya meskipun peranan setiap sektor menunjukkan angka yang semakin berimbang.

\section{Distribusi Persentase PDRB menurut Lapangan Usaha Atas Dasar Harga Berlaku}

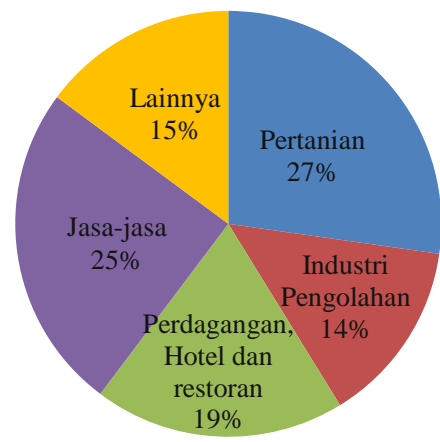

Sumber : BPS Kabupaten Pontianak, 2013

Gambar 1. Struktur Perekonomian Kabupaten Pontianak 
Berdasarkan Tabel 1 dan Gambar 1, maka sektor pertanian merupakan penyumbang terbesar dari PDRB di Kabupaten Mempawah. Oleh karena itu, dilakukan penelitian mengenai komoditas apa saja yang merupakan komoditas unggulan sektor pertanian di Kabupaten Mempawah, khususnya subsektor tanaman bahan makanan yang meliputi tanaman pangan dan hortikultura.

Berdasarkan nilai PDRB di Kabupaten Mempawah pada rentang tahun 2008-2012, sektor pertanian subsektor tanaman bahan makanan mempunyai nilai yang paling tinggi diantara subsektor lainnya. Disamping itu, subsektor tanaman bahan makanan mencakup kebutuhan pokok manusia sehingga diperlukan penelitian yang mendalam agar subsektor tanaman bahan makanan dapat berkembang kearah yang lebih baik dan dapat memenuhi kebutuhan hidup masyarakat secara kontinu.

Perumusan Masalah

Permasalahan dalam penelitian ini, yaitu:

1. Subsektor apa yang menjadi basis pada sektor pertanian di Kabupaten Mempawah?

2. Komoditas apa saja yang merupakan unggulan dari tanaman pangan dan hortikultura dari sisi produksi di Kabupaten Mempawah?

\section{Tujuan Penelitian}

Tujuan dari penelitian ini, yaitu:

1. Untuk menganalisis subsektor yang menjadi basis pada sektor pertanian di Kabupaten Mempawah.

2. Untuk menganalisis komoditas yang merupakan unggulan dari tanaman pangan dan hortikultura dari sisi produksi di Kabupaten Mempawah.

\section{METODE PENELITIAN}

\section{Lokasi Penelitian}

Berdasarkan Peraturan Pemerintah Republik Indonesia Nomor 58 tahun 2014 nama Kabupaten Pontianak mengalami perubahan menjadi Kabupaten Mempawah. Mengingat Kabupaten Mempawah merupakan salah satu basis pembangunan pertanian untuk Provinsi Kalimantan Barat, maka penelitian ini dilaksanakan di Kabupaten Mempawah Provinsi Kalimantan Barat.

\section{Teknik Pengumpulan dan Sumber Data}

Data yang digunakan dalam penelitian ini adalah time series data yaitu data sekunder PDRB Kabupaten Mempawah Atas Dasar Harga Konstan tahun 2008 sampai dengan 2012, data sekunder PDRB Provinsi Kalimantan Atas Dasar Harga Konstan 2008 sampai dengan 2012, data nilai produksi komoditas sektor pertanian 2008 sampai dengan 2012.

\section{Analisis Data}

Analisis Dynamic Location Quotient (DLQ) digunakan untuk menentukan basis dan non basis sektor pertanian serta sektor unggulan komoditas pertanian wilayah maupun komoditas-komoditas unggulan dari suatu daerah. Analisis Dynamic Location Quotient (DLQ) adalah modifikasi dari Analisis $L Q$, dengan mengakomodasi faktor laju pertumbuhan keluaran sektor ekonomi dari waktu ke waktu. Nilai dari Analisis $D L Q$ dihitung menggunakan rumus sebagai berikut (Cholid, 2013):

$$
D L Q=\left[\frac{\left(1+g_{i j}\right) /\left(1+g_{j}\right)}{\left(1+G_{i}\right) /(1+G)}\right]^{t}
$$


Keterangan :

$\mathrm{g}_{\mathrm{ij}}=$ Laju pertumbuhan PDRB sektor i di Kabupaten Mempawah

$\mathrm{g}_{\mathrm{j}}=$ Rata-rata laju pertumbuhan PDRB total sektor $i$ di Kabupaten Mempawah

$\mathrm{G}_{\mathrm{i}}=$ Laju pertumbuhan sektor $i$ total di Provinsi Kalimantan Barat

$\mathrm{G}=$ Rata-rata laju pertumbuhan sektor di Provinsi Kalimantan Barat

$\mathrm{t}=$ selisih tahun akhir dan tahun awal

Kriteria pengukuran nilai $D L Q$ yang dihasilkan yaitu sebagai berikut:

a. Apabila nilai $D L Q>1$, maka potensi perkembangan komoditas $i$ ditingkat kabupaten lebih cepat dibandingkan komoditas yang sama ditingkat Provinsi dan dapat diharapkan untuk menjadi sektor basis pada masa yang akan datang.

b. Apabila nilai $D L Q<1$, maka potensi perkembangan komoditas $i$ ditingkat kabupaten lebih rendah dibandingkan ditingkat Provinsi secara keseluruhan dan tidak dapat diharapkan untuk menjadi sektor basis di masa yang akan datang.

Analisis Shift-Share adalah salah satu teknik kuantitatif yang biasa digunakan untuk menganalisis perubahan struktur ekonomi daerah relatif terhadap struktur ekonomi wilayah administratif yang lebih tinggi sebagai pembanding atau referensi (Hairuddin, 2002).

$$
D_{i j}=N_{i j}+M_{i j}+C_{i j}
$$

Keterangan:

$D_{i j}=$ Perubahan variabel daerah (nilai produksi komoditas $i$ ) di wilayah $j$

$N_{i j}=$ Pengaruh komponen laju pertumbuhan daerah acuan (Provinsi)

$M_{i j}=$ pengaruh komponen bauran industri daerah acuan (Provinsi)

$C_{i j}=$ pengaruh komponen persaingan / kedudukan kompetitif

Kriteria keputusan yang dapat diambil untuk nilai Shift Share adalah:

- Jika $\mathrm{N}_{\mathrm{ij}}$ bernilai positif berarti laju pertumbuhan Kabupaten Mempawah tumbuh lebih cepat dibandingkan laju pertumbuhan Provinsi Kalimantan Barat rata - rata.

- Jika $\mathrm{N}_{\mathrm{ij}}$ bernilai negatif berarti laju pertumbuhan Kabupaten Mempawah tumbuh lebih lambat dibandingkan laju pertumbuhan Provinsi Kalimantan Barat rata - rata.

- Jika $\mathrm{M}_{\mathrm{ij}}$ bernilai positif berarti laju pertumbuhan sektor ke-i tumbuh lebih cepat daripada pertumbuhan ekonomi secara keseluruahan.

- Jika $\mathrm{M}_{\mathrm{ij}}$ bernilai negatif berarti laju pertumbuhan sektor ke-i tumbuh lebih lambat.

- Jika $\mathrm{C}_{\mathrm{ij}}$ bernilai positif berarti sektor tersebut memiliki daya saing yang tinggi.

- Jika $\mathrm{C}_{\mathrm{ij}}$ bernilai negatif berarti sektor tersebut tidak memiliki daya saing.

Analisis Model Rasio Pertumbuhan merupakan modifikasi lebih lanjut dari analisis Shift-Share. Analisis MRP mempunyai dua rasio pertumbuhan yaitu Rasio Pertumbuhan Daerah Referensi $\left(\mathrm{RP}_{\mathrm{r}}\right)$ dan Rasio Pertumbuhan Daerah Studi $\left(R_{\mathrm{s}}\right)$. Nilai rasio kedua pertumbuhan tersebut diperoleh dengan persamaan sebagai berikut (Yusuf, 1999):

$$
R P_{r}=\frac{\Delta P_{i} R / P_{i} R_{(t)}}{\Delta P R / P R_{(t)}}
$$




$$
R P_{s}=\frac{\Delta P_{i j} / P_{i j(t)}}{\Delta P_{i} R / P_{i} R_{(t)}}
$$

Keterangan:

$\Delta P_{i} R=$ Perubahan nilai produksi komoditas $i$ di wilayah Provinsi

$P_{i} R_{(t)}=$ Nilai produksi komoditas $i$ di wilayah Provinsi pada awal periode penelitian

$P R=$ Perubahan nilai produksi total di daerah Provinsi

$P R_{(t)} \quad=$ Nilai produksi total di wilayah Provinsi pada awal periode penelitian

$P_{i j} \quad=$ Perubahan nilai produksi komoditas $i$ di daerah kabupaten

$P_{i j(t)}=$ Nilai produksi komoditas $i$ di daerah kabupaten pada awal periode penelitian.

Berikut keterangan dari hasil Analisis Model Rasio Pertumbuhan:

1. Jika nilai dari Rasio Pertumbuhan Daerah Referensi $\left(\mathrm{RP}_{\mathrm{r}}\right)$ lebih besar dari satu (>1), maka nilai $\mathrm{RP}_{\mathrm{r}}$ dikatakan positif (+). Hal ini menunjukkan bahwa pertumbuhan nilai produksi komoditas tertentu dalam wilayah referensi (Provinsi) lebih tinggi dari pertumbuhan total nilai produksi di wilayah referensi tersebut.

2. Jika nilai Rasio Pertumbuhan Daerah Referensi $\left(\mathrm{RP}_{\mathrm{r}}\right)$ lebih kecil dari satu $(<1)$ maka nilai $\mathrm{RP}_{\mathrm{r}}$ dikatakan negatif $(-)$, berarti pertumbuhan nilai produksi komoditas tertentu lebih kecil dari pertumbuhan total produksi di wilayah referensi.

3. Jika nilai Rasio Pertumbuhan Daerah Studi $\left(\mathrm{RP}_{\mathrm{s}}\right)$ lebih besar dari satu $(>1)$ maka $\mathrm{RP}_{\mathrm{s}}$ dikatakan positif (+), yang berarti pertumbuhan nilai produksi komoditas tertentu di wilayah studi (kabupaten) lebih tinggi dari pertumbuhan nilai produksi komoditas tersebut di daerah referensi (Provinsi).

4. Jika nilai Rasio Pertumbuhan Daerah Studi $\left(\mathrm{RP}_{\mathrm{s}}\right)$ lebih kecil dari satu $(<1)$ maka $\mathrm{RP}_{\mathrm{s}}$ dikatakan negatif (-), berarti pertumbuhan nilai produksi komoditas tertentu di wilayah studi (kabupaten) lebih kecil dibanding dengan laju pertumbuhan produksi di wilayah referensi (Provinsi).

\section{HASIL DAN PEMBAHASAN}

Analisis Penentuan Basis dan Non Basis Sektor Pertanian di Kabupaten Mempawah

Analisis $D L Q$ menggunakan laju pertumbuhan dengan asumsi bahwa setiap nilai tambah sektoral maupun PDRB mempunyai rata-rata laju pertumbuhan per tahun sendiri-sendiri selama kurun waktu tahun awal dan tahun berjarak. Hasil dari analisis DLQ terhadap sektor pertanian di Kabupaten Mempawah dapat dilihat dalam tabel 2.

Tabel 2. Rata-rata Nilai DLQ Sektor Pertanian di Kabupaten Pontianak Tahun $2008-2012$

\begin{tabular}{lcc}
\hline \multicolumn{1}{c}{ Sektor } & $\begin{array}{c}\text { Rata-rata Nilai } \\
\text { DLQ }\end{array}$ & Keterangan \\
\hline Tanaman Bahan Makanan & 1,08 & Basis \\
Tanaman Perkebunan & 0,99 & Non Basis \\
Peternakan dan Hasil-hasilnya & 0,90 & Non Basis \\
Kehutanan & 1,19 & Basis \\
Perikanan & 1,13 & Basis \\
\hline \multicolumn{1}{c}{ Sumber : Lampiran 8, 9, 12 dan 13 (diolah) } & & \\
\hline \hline
\end{tabular}


Berdasarkan tabel 2, subsektor pertanian yang diproyeksikan menjadi basis pada masa yang akan datang adalah subsektor tanaman bahan makanan, subsektor kehutanan dan subsektor perikanan. Sedangkan subsektor tanaman perkebunan dan subsektor peternakan dan hasil-hasilnya bukan merupakan basis dari sektor pertanian.

Adapun hasil analisis sebagaimana tersaji dalam tabel 2 dapat dijelaskan sebagai berikut:

1. Subsektor Tanaman Bahan Makanan

Nilai DLQ dari subsektor tanaman bahan makanan adalah 1,08. Artinya subsektor tanaman bahan makanan merupakan basis sektor pertanian di Kabupaten Mempawah tahun 2008 - 2012. Sektor pertanian merupakan penyumbang terbesar terhadap pembentukan PDRB Kabupaten Pontianak, yakni sebesar 27,3 persen. Angka ini diambil dari rata-rata kontribusi sektor pertanian terhadap PDRB Kabupaten Pontianak selama kurun waktu 2008 - 2012. Disamping itu, kontribusi dari subsektor tanaman bahan makanan terhadap sektor pertanian merupakan yang terbesar dibandingkan subsektor yang lainnya.

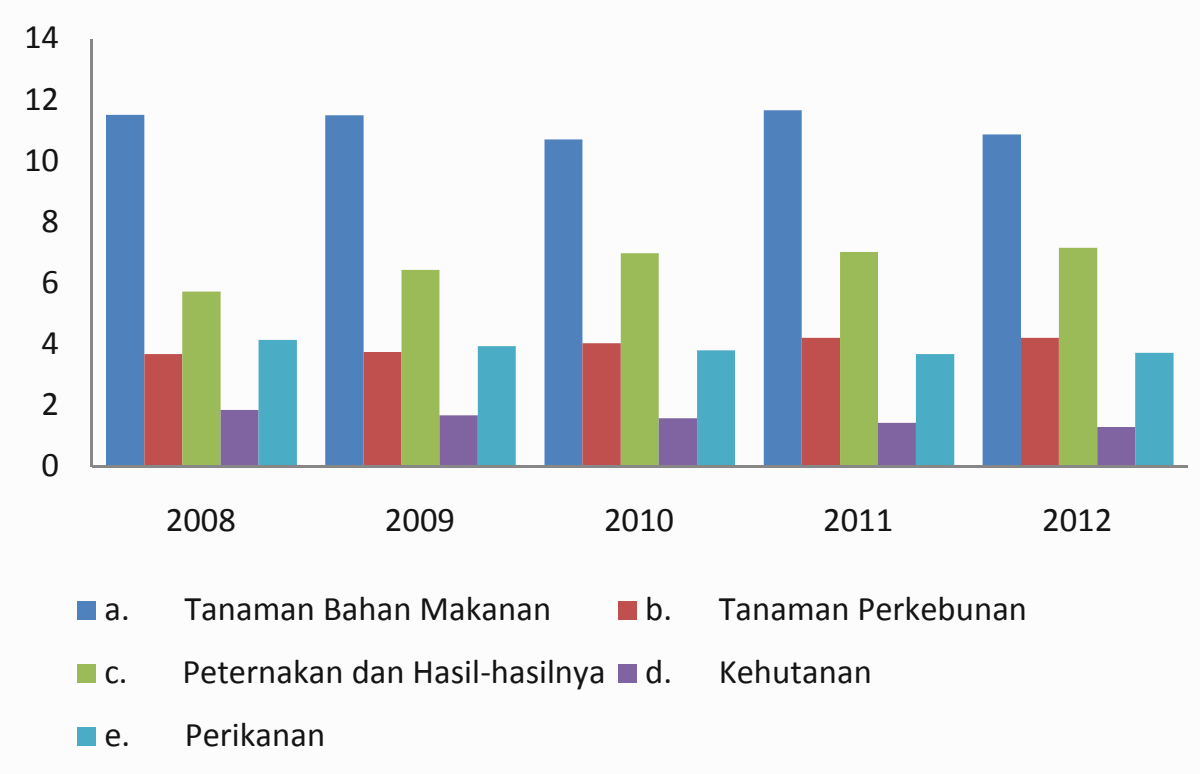

Sumber: Indikator Ekonomi Kab. Pontianak Tahun 2012

Gambar 2. Kontribusi PDRB Sektor Pertanian Kabupaten Pontianak Tahun 2008 - 2012 (Persen)

Gambar 2 menunjukkan bahwa kontribusi PDRB subsektor tanaman bahan makanan terhadap PDRB sektor pertanian selama kurun waktu 2008 - 2012. Meskipun kontribusi PDRB dari subsektor tanaman bahan makanan cukup berfluktuatif namun selalu menjadi yang paling dominan diantara subsektor yang lainnya.

Sentra produksi tanaman bahan makanan di Kabupaten Mempawah terletak di Kecamatan Anjungan, dengan kontribusi sektoral terhadap PDRB tahun 2012 sebesar 18,74 persen. Kecamatan Anjungan mempunyai kontur tanah yang mendukung untuk bercocok tanam baik untuk tanaman pangan maupun tanaman hortikurtura, sehingga hasil produksinya maksimal. 


\section{Subsektor Tanaman Perkebunan}

Nilai DLQ untuk subsektor tanaman perkebunan sebesar 0,99. Hal ini berarti subsektor tanaman perkebunan bukan merupakan basis sektor pertanian di Kabupaten Mempawah. Kontribusi rata-rata subsektor perkebunan terhadap PDRB sektor pertanian sebesar 3,97 persen. Produksi perkebunan masih didominasi oleh tanaman kelapa dan karet, yang merupakan tanaman yang paling banyak diusahakan oleh rakyat dari tahun ke tahun. Sentra produksi dari subsektor perkebunan terkonsentrasi di Kecamatan Sungai Kunyit dengan kontribusi terhadap PDRB pada tahun 2012 sebesar 19,39 persen.

3. Subsektor Peternakan dan Hasil-hasilnya

Nilai DLQ untuk subsektor peternakan dan hasil-hasilnya adalah 0,90. Ini berarti subsektor peternakan dan hasil-hasilnya bukan merupakan basis sektor pertanian di Kabupaten Mempawah. Berdasarkan hasil produksinya, Kecamatan Sungai Kunyit mempunyai kontribusi terbesar terhadap PDRB sektoral Kabupaten Mempawah pada tahun 2012 yakni sebesar 12,72 persen dibandingkan dengan kecamatan yang lainnya.

\section{Subsektor Kehutanan}

Nilai $D L Q$ untuk subsektor kehutanan adalah 1,19. Artinya subsektor kehutanan merupakan basis sektor pertanian di Kabupaten Mempawah. Tahun 2012 luas kawasan hutan di Kabupaten Mempawah sekitar 0,15 Ha. Hal ini menjadikan Kabupaten Mempawah merupakan salah satu kabupaten yang memiliki kawasan hutan yang cukup luas yaitu sekitar 1,65 persen dari seluruh luas kawasan hutan di Provinsi Kalimantan Barat.

Menurut data Dinas Pertanian, Peternakan, Perkebunan dan Kehutanan luas kawasan hutan di Kabupaten Mempawah pada tahun 2012 terdiri dari 3,60 persen hutan lindung, 11,40 persen hutan produksi terbatas, 36,99 persen hutan produksi biasa dan 48,01 persen merupakan areal penggunaan lain. Hasil produksi terbanyak dari subsektor kehutanan terletak di Kecamatan Siantan dengan kontribusi sektoral terhadap PDRB Kabupaten Mempawah sebesar 19,85 persen.

5. Subsektor Perikanan

Nilai DLQ subsektor perikanan adalah 1,13. Artinya subsektor perikanan merupakan basis sektor pertanian di Kabupaten Mempawah dan diproyeksikan tetap bisa menjadi basis sektor pertanian di Kabupaten Mempawah pada masa yang akan datang. Kecamatan Sungai Pinyuh merupakan kecamatan dimana subsektor perikanan mempunyai nilai tertinggi dari kontribusi sektoral terhadap PDRB sektor pertanian di Kabupaten Mempawah tahun 2012 yakni sebesar 28,17 persen.

Jika dilihat secara keseluruhan, perekonomian di Kabupaten Mempawah sedang menuju kearah yang lebih baik. Hal ini terlihat dari hasil DLQ di tiga subsektor mempunyai nilai lebih dari 1. Ini mengindikasikan bahwa sektor perekonomian di Kabupaten Mempawah mempunyai peluang pasar yang cerah dan mampu memenuhi kebutuhan daerah sendiri. Selanjutnya diharapkan Kabupaten Mempawah dapat mengekspor hasil produksinya keluar daerah.

Analisis Penentuan Komoditas Unggulan Tanaman Pangan dan Hortikultura di Kabupaten Mempawah

Analisis Shift-Share digunakan untuk mengukur perubahan ekonomi (pertambahan atau penurunan) di Kabupaten Mempawah, yang hasilnya untuk menganalisa komponen yang menyebabkan perubahan Produk Domestik Regional 
Bruto (PDRB) nyata dari masing-masing subsektor. Analisis ini juga digunakan untuk mengetahui kinerja komoditas pertanian selama periode pengamatan di Kabupaten Mempawah.

Berdasarkan hasil perhitungan analisis Shift-Share diperoleh hasil yang dapat dijelaskan sebagai berikut:

- Komponen laju pertumbuhan daerah $\left(\mathrm{N}_{\mathrm{ij}}\right)$

Komoditas yang mempunyai dampak positif tertinggi terhadap perubahan pertambahan nilai produksi pertanian Provinsi Kalimantan Barat adalah pisang dengan nilai 282.574,45 juta rupiah kemudian disusul dengan komoditas padi, nenas, cabe, ubi kayu, kacang panjang, durian dan ketimun. Sedangkan untuk komoditas yang lainnya hanya mempunyai peranan dibawah 3 Milyar rupiah.

- Komponen bauran industri $\left(\mathrm{M}_{\mathrm{ij}}\right)$

Pada komponen ini sebagian komoditas menunjukkan kinerja yang negatif. Hal ini berarti pengaruh bauran industri di Kabupaten Mempawah pada kurun waktu 2008 - 2012 perkembangannya lebih rendah dari perkembangan komoditi yang sama di Provinsi Kalimantan Barat. Adapun komoditas yang menunjukkan kinerja positif sebagai berikut, untuk kelompok tanaman bahan pangan adalah padi, ubi jalar dan kacang hijau, untuk kelompok sayur-sayuran terdiri dari sawi, tomat, dan buncis, dan untuk kelompok buah-buahan mayoritas menunjukkan kinerja yang positif. Selain komoditas tersebut komoditas lain yang menunjukkan kinerja yang negatif pada kelompok ini yaitu untuk komoditas pisang dan cempedak, sedangkan komoditas yang lain menunjukkan kinerja yang positif, dimana nenas merupakan komoditas dengan kinerja positif yang tertinggi.

- Komponen keunggulan kompetitif $\left(\mathrm{C}_{\mathrm{ij}}\right)$

Komoditas pertanian di Kabupaten Mempawah yang mempunyai keunggulan kompetitif yaitu pada kelompok tanaman bahan pangan adalah ubi kayu, ubi jalar, kacang tanah dan kacang kedelai. Komoditas yang tidak mempunyai keunggulan kompetitif adalah padi, jagung dan kacang hijau, sedangkan pada kelompok sayur-sayuran yang mempunyai keunggulan kompetitif hanya daun bawang, untuk sayur-sayuran lainnya tidak mempunyai keunggulan kompetitif. Kelompok buah-buahan yang mempunyai keunggulan kompetitif adalah jeruk, durian, dan cempedak, sedangkan rambutan, mangga, pepaya, pisang, dan nenas tidak mempunyai keunggulan kompetitif.

Jika dilihat pada subsektor tanaman bahan makanan, komoditas yang mempunyai nilai kontribusi tertinggi adalah jeruk dengan nilai 27.304,92 juta rupiah. Namun sektor pertanian di Kabupaten Mempawah mempunyai nilai keunggulan kompetitif $\mathbf{- 9 2 , 9 6}$ Milyar rupiah. Ini berarti sektor pertanian di Kabupaten Mempawah mengalami penurunan daya saing dibandingkan dengan sektor yang sama di tingkat Provinsi Kalimantan Barat.

Analisis Model Rasio Pertumbuhan merupakan modifikasi lebih lanjut dari analisis Shift-Share. Analisis MRP dilakukan untuk melihat deskripsi kegiatan ekonomi yang menekankan pada kriteria pertumbuhan baik secara eksternal (provinsi) maupun secara internal (kabupaten).

Hasil dari analisis ini dibagi menjadi empat klasifikasi, yaitu:

1. Klasifikasi I, RPr (+) dan RPs (+)

Klasifikasi ini menunjukkan bahwa komoditas tersebut mempunyai pertumbuhan yang tinggi baik di daerah Provinsi maupun Kabupaten. Komoditas 
yang termasuk dalam klasifikasi ini pada kelompok tanaman bahan pangan adalah padi, kacang kedelai, ubi kayu, ubi jalar, kacang tanah dan kacang hijau.

Kelompok sayur-sayuran komoditas yang termasuk dalam klasifikasi ini adalah terung, bayam, tomat dan daun bawang, sedangkan untuk kelompok buahbuahan komoditas yang termasuk dalam klasifikasi ini adalah rambutan, jeruk, durian, mangga, pepaya, nenas, dan cempedak.

2. Klasifikasi II, RPr (+) dan RPs (-)

Klasifikasi ini menunjukkan bahwa komoditas tersebut mempunyai pertumbuhan yang tinggi di daerah Provinsi namun kurang tinggi di daerah kabupaten. Komoditas yang termasuk klasifikasi ini adalah jagung, sawi, kacang panjang, cabe dan buncis. Untuk kelompok buah-buahan tidak ada yang masuk dalam klasifikasi ini.

3. Klasifikasi III, RPr (-) dan RPs (+)

Klasifikasi ini menunjukkan bahwa komoditas tersebut mempunyai pertumbuhan yang kurang tinggi di daerah Provinsi namun tinggi di daerah kabupaten. Komoditas yang termasuk klasifikasi ini adalah ketimun, kangkung, dan pisang.

Kecamatan Mempawah Timur menghasilkan produksi kangkung dan ketimun tertinggi dibandingkan dengan kecamatan lain di Kabupaten Mempawah. Sedangkan komoditas pisang tertinggi dihasilkan di Kecamatan Sungai Kunyit dan terrendah dihasilkan oleh Kecamatan Sadaniang yaitu hanya menghasilkan 14,20 ton.

4. Klasifikasi IV, RPr (-) dan RPs (-)

Klasifikasi ini menunjukkan bahwa komoditas tersebut mempunyai pertumbuhan yang tidak menonjol baik di daerah Provinsi maupun Kabupaten.

Rata-rata komoditas tanaman pangan dan hortikultura di Kabupaten Mempawah mempunyai pertumbuhan yang menonjol baik di Kabupaten Mempawah maupun di Provinsi Kalimantan Barat. Komoditas yang pertumbuhannya menonjol baik di Kabupaten Mempawah maupun di Provinsi Kalimantan Barat adalah padi, kacang kedelai, ubi kayu, ubi jalar, kacang tanah, dan kacang hijau untuk kelompok tanaman bahan pangan; terung, bayam, tomat, dan daun bawang untuk kelompok sayur-sayuran; sedangkan untuk kelompok buah-buahan yaitu rambutan, jeruk, durian, mangga, pepaya, nenas dan cempedak. Komoditas yang pertumbuhannya tidak menonjol di Provinsi Kalimantan Barat adalah ketimun, kangkung dan pisang. Sedangkan komoditas yang pertumbuhannya tidak menonjol di Kabupaten Mempawah adalah jagung, sawi, kacang panjang, cabe dan buncis.

\section{KESIMPULAN DAN SARAN}

\section{Kesimpulan}

Berdasarkan hasil analisa data, maka dapat diambil kesimpulan sebagai berikut:

1. Sektor pertanian di Kabupaten Mempawah yang menjadi basis adalah subsektor tanaman bahan makanan, subsektor kehutanan dan subsektor perikanan. Sedangkan subsektor perkebunan dan subsektor peternakan bukan merupakan basis di Kabupaten Mempawah. 
2. Komoditas pertanian yang mempunyai dampak positif terhadap perubahan pertambahan nilai produksi pertanian dan menunjukkan kinerja positif serta keunggulan kompetitif yang positif adalah ubi jalar, jeruk, dan durian.

3. Komoditas unggulan di Kabupaten Mempawah dan mempunyai potensi menjadi komoditas unggulan Provinsi Kalimantan Barat adalah ketimun, kangkung dan pisang.

\section{Saran}

1. Pemerintah Kabupaten Mempawah hendaknya memberikan penyuluhan dan pelatihan kepada para petani guna meningkatkan hasil produksi sektor pertanian subsektor tanaman bahan makanan, karena subsektor ini mempunyai kontribusi PDRB yang paling tinggi dibandingkan subsektor lainnya. Mengingat tanaman bahan makanan merupakan kebutuhan pokok masyarakat sehingga ketersediaannya harus dijamin secara kontinu.

2. Pemerintah Kabupaten Mempawah diharapkan dapat menyediakan lahan khusus untuk menanam komoditas ketimun dan kangkung, karena selama ini kedua komoditas tersebut ditanam sebagai tanaman tumpangsari dan belum memberikan hasil yang maksimal. Hal ini dikarenakan kedua komoditas tersebut merupakan komoditas unggulan di Kabupaten Mempawah namun belum menjadi komoditas unggulan di Provinsi Kalimantan Barat, sehingga diharapkan pada masa yang akan datang kedua komoditas ini menjadi komoditas unggulan baik di Kabupaten Mempawah maupun di Provinsi Kalimantan Barat.

\section{DAFTAR PUSTAKA}

Badan Pusat Statistik Provinsi Kalimantan Barat. 2013. Provinsi Kalimantan Barat dalam Angka 2013. BPS Propinsi Kalimantan Barat.

Badan Pusat Statistik Kabupaten Pontianak. 2013. Kabupaten Pontianak dalam Angka 2013. BPS Kabupaten Pontianak.

Badan Perencanaan Pembangunan Daerah dan Badan Pusat Statistik Kabupaten Pontianak. 2013. Indikator Ekonomi Kabupaten Pontianak Tahun 2012. Bappeda dan BPS Kabupaten Pontianak.

Cholid, I . 2013. Analisis Sektor Unggulan Perekonomian dan Komoditas Pertanian di Kabupaten Kayong Utara [skripsi]. Fakultas Pertanian Universitas Tanjungpura, Pontianak.

Didu. 2000. Pembangunan Agribisnis berbasis Sektor Unggulan Wilayah di Jawa Barat [tesis]. Program Pasca Sarjana IPB. Bogor.

Hairuddin. 2002. Analisis Komoditas Unggulan Pertanian Kabupaten Kota Baru [tesis]. Program Pasca Sarjana UGM. Yogyakarta.

Saragih, B. 2001. Agribisnis Paradigma Baru Pembangunan Ekonomi Berbasis Pertanian. Yayasan Mulia Pesada. Bogor.

Suhariyono, A, K. 2013. Analisis Struktur Perekonomian dan Pertumbuhan Ekonomi di Provinsi Banten Melalui Pendekatan LQ, Shift-Share [skripsi]. Universitas Negeri Semarang.

Yusuf, M. 1999. Model Rasio Pertumbuhan (MRP) sebagai Salah Satu Alat Analisis Alternatif dalam Perencanaan Wilayah dan Kota : Aplikasi Model Wilayah Bangka-Belitung. Jurnal Ekonomi dan Keuangan Indonesia Vol XLVII No.2 1999. 